\title{
ANGELA CARTER'S THE BLOODY CHAMBER: A FEMINIST STYLISTIC APPROACH ${ }^{1}$
}

\author{
Angela Carter'ın The Bloody Chamber Adlı Anlatısı: Feminist Deyişbilimsel Bir Yaklaşım
}

\section{Seda ARIKAN ${ }^{2}$}

\begin{abstract}
Stylistics, the study of a writer's style, has incorporated various approaches, especially in the last few decades. Therefore, feminist stylistics based on the theories of feminist criticism appears as a significant approach defining "woman" and her place not only in society, but also in language. By examining male domination in society and literary works, feminist stylistics tries to present a counter-image of women both in language and social construction. The tendency of current feminist stylistics mostly focuses on the idea that there is a significant "women's writing and style" that differs from men's. These linguistic and thematic differences that are called "genderlect" or "gendered sentence" in women's writing are the main interest of feminist stylistics. This study will depict the "genderlect" and "gendered" style in Angela Carter's The Bloody Chamber.

Carter's The Bloody Chamber, a collection of re-written traditional fairy tales, "extracts the latent content from the traditional stories" in Carter's words. Ten stories in the collection handle the topics of marriage, sexuality, gender roles, and female liberty with a subverting point of view. In this article, three stories narrated by female first-person narrators in this collection will be analyzed in terms of lexico-semantic items in the narration, and Carter's style as an example of écriture féminine will be examined with regard to feminist stylistics.
\end{abstract}

Key Words: feminist stylistics, Angela Carter, The Bloody Chamber, genderlect, gendered style.

\section{Özet}

Bir yazarın yazın üslubunu inceleyen deyişbilim özellikle son yirmi otuz yıldır çeşitli yaklaşımları bir araya getirmiştir. $\mathrm{Bu}$ nedenle, feminist eleştiri üzerine temellenen feminist deyişbilim, kadını ve kadının konumunu sadece toplumda değil dilde de tanımlayan önemli bir yaklaşım olarak ortaya çıkar. Feminist deyişbilim, toplumdaki ve edebi eserlerdeki erkek egemenliğini inceleyerek, hem dil hem de toplum yapılanmasında kadın için bir karşı-imge sunmaya çalışır. Mevcut feminist deyişbilim yaklaşımı, erksel olandan ayrılan önemli bir "kadın yazını ve deyiş̧i" olduğu fikrine yoğunlaşır. Kadın yazınındaki "toplumsal cinsiyet değişkesi" ya da "toplumsal cinsiyetli deyiş" olarak adlandırılan bu dilbilimsel ve tematik farklar feminist deyişbilimin en temel ilgi alanıdır. Bu çalışma, Angela Carter'ın The Bloody Chamber adlı anlatısında "toplumsal cinsiyet değişkesi" ya da "toplumsal cinsiyetli deyiş"i dile getirecektir.

Geleneksel masalların yeniden yazıldı̆̆ı bir derlem olan Carter'n The Bloody Chamber anlatısı, Carter'ın kendi deyişiyle "geleneksel öykülerdeki gizil içeriği ortaya çıkarır". Derlemdeki on öykü evlilik, cinsellik, toplumsal cinsiyet ve kadın özgürlüğü konularını düzeni bozan bir bakış açısı ile ele almaktadır. Bu makalede, derlemden seçilmiş, birinci şahıs kadın anlatıcılar tarafindan aktarılan üç öykü anlatıdaki sözcükanlambilimsel öğeler açısından irdelenecek, écriture féminine örneği olarak Carter'ın üslubu feminist deyişbilim bakımından incelenecektir.

Anahtar Kelimeler: feminist deyişbilim, Angela Carter, The Bloody Chamber, toplumsal cinsiyet değişkesi, toplumsal cinsiyetli deyiş.

\section{Introduction}

"To narrate is to exercise power" says distinguished literary critic Terry Eagleton ${ }^{3}$ and the twentieth century witnessed many writers narrating to subvert earlier power relations, creating a

\footnotetext{
${ }^{1}$ This article is a revised and expanded version of a paper with the same title, presented at 15 th International Stylistics Symposium at Akdeniz University in October-2015.

${ }^{2}$ Assist. Prof. Dr. Frrat University Faculty of Humanities Department of Western Languages and Literatures e-mail: bulutsedaarikan@gmail.com
} 


\section{F.Ü. Sosyal Bilimler Dergisi 2016-26/2}

new perception of those relations. Feminism -parallel with feminist criticism- was one of the prominent voices that stood against the dominating powers, especially patriarchy. When for feminists "[v]alue, speech, image, experience and identity" became "the very language of political struggle" (Eagleton, 2003, 47), many women writers started to decode the latent meanings in texts narrated by ruling sexist male ideology and to retell some earlier writings from the female point of view. In terms of the intention of women writers to retell the texts serving for patriarchal power, it could be said that fairy tales took the leading place. Fairy tales that go beyond being a part of certain cultures have the significant effect to reflect the background of a society, and also to contribute to the creation of a collective unconscious. When Carl Jung published studies in the first half of the twentieth century that stressed the substantial impact of collective unconscious, and its certifying elements that are the archetypes found as common representatives in different cultures, the myths, legends and fairy tales became more of an issue for feminist criticism to analyze the discourses of patriarchal power. In this respect, the feminist novelist Angela Carter -in her collection of short fiction The Bloody Chamber published in 1979- retold traditional fairy tales known and even internalized by many people. Carter clearly mentions that her intention "was not to do 'versions' or, as the American edition of the book said, horribly, 'adult' fairy tales, but to extract the latent content from the traditional stories" (Haffenden, 1985, 80). This latent content that establishes the collective unconscious of humanity about female and male identities and their stereotypical characteristics is challenged by Carter in these short stories with a new representation of female and male characters. She states her concern as follows: "I'm in the demythologizing business. I'm interested in myths - though I'm much more interested in folklore - just because they are extraordinary lies designed to make people unfree" (Carter, 1998a, 25). The earlier representation of female and male figures in fairy tales are explicitly presented as an achievement of patriarchal power by Carter. By challenging the archetypal characters and stereotypical female and male figures, Carter re-examines the themes of marriage, sexuality, power relations between females and males, gender roles, and female liberty. Standing against the oppression by males, she announces the liberation of females in fairy tales.

"As a writer, Carter is usually associated with fantasy, the Gothic, the bizarre, the fairy tale, the burlesque, the mythical, magical and metaphorical, all of which transport us away from historical actuality into a primarily symbolic literary space" (Joannou, 2007, 111-2). The power of language and discourse, as many intellectuals have foreseen, is the main weapon in Carter's stories. In Carter's subverted stories, not only the content but also the writer's style serves Carter's aim to extract and deconstruct the latent content based on the traditional misogynist attitude. Thus, "feminist stylistics" labelled by Sara Mills in her book, titled with the same name, appears as a suitable approach to analyze Carter's stories. At the beginning of her book, Mills explains the concern of feminist stylistic analysis as follows:

Feminist stylistic analysis is concerned not only to describe sexism in a text, but also to analyze the way that point of view, agency, metaphor, or transitivity are unexpectedly closely related to matters of gender, to discover whether women's writing practices can be described, and so on. (Mills, 1995, 1)

A feminist stylistic analysis tries to infer the overt or latent sexism in a text, to relate content and style of a text with gender issues, and to make a survey on écriture féminine, in the words of Helene Cixous. While feminist criticism aims to deconstruct the established gender roles and identities in content with discourse analysis, feminist stylistics focuses on both discourse and also the way and style in which the discourse is revealed. When Sara Mills specifies the field of feminist stylistics, she links it with literary stylistics, critical linguistics, Michael Halliday's systemic linguistics, and discourse stylistics, all of whose common point goes beyond the theoretical models

\footnotetext{
${ }^{3}$ Terry Eagleton. From his Keynote Speech at "1st International Conference on English Language and Literary Studies CELLS," University of Banja Luka, Bosnia and Herzegovina, June-2013.
} 
of linguistics and steps into the factors outside the text. Mills claims that stylistics should not ignore the context and factors such as race, class, and gender when analyzing a text; besides, according to her, to analyze a text totally in isolation is "an outdated inheritance" (Mills, 1995, 5). Thus, the relationship between language and social forces gives the approaches, including feminist stylistics, the opportunity to adopt a political perspective against the ideological messages inserted in texts. This is the significant notion Althusser and Foucault theorized about and many feminists improved their theories. As it is well-accepted now, ideology and literature as its apparatus, inject restrictive, oppressive, and controlling social meanings and structures into the collective unconscious of societies. For this reason, the ideology that is buried within language is the main rival against which feminist stylistics attacks. By making clear that "reality is organized along gendered lines" (Mills, 1995, 11), feminist stylistics examines genderlect that is "the linguistic differences in the way men and women perceive social reality" (Ufot, 2012, 2463) for the benefit of females. Adopting a political stance, feminist stylistics

[...] aims to lead stylistics away from analysis of the language of the text, as if that language were simply there, to an analysis of socioeconomic factors which have allowed that language to appear, or which have determined its appearance, or which have determined the type of interpretations of that text which are possible. (Mills, 1995, 17)

Besides interpreting the texts and decoding the patriarchal discourses in terms of content and subject matter as earlier feminist criticisms have followed out, feminist stylistics also focuses on the production and process of discourse and "the interaction between the text and the reader in the production of interpretations" (Mills, 1995, 66). At this point, Sara Mills insistently asserts that "feminist stylistics is not simply an academic exercise, it is primarily political [italics added]" (Mills, 1995, 40-1).

In brief, a feminist stylistic analysis aims to "read against the grain" and turn the traditional discourses upside down by the power of language. Mills states that "a great deal of western literature is concerned with a description of women's experience, by men" (Mills, 1995, 53) and among those literary works fairy tales are the prominent ones. Carter's The Bloody Chamber appears as a challenge to the earlier narrations about female experience, and presents the experience through the female mind as opposed to the male-dominant ideology as in the previous fairy tales. Many feminists find fairy tales as male fantasies on female and sexist discourses, as they encourage or imply the oppression of female sexism. That's why retelling the fairy tales not through male-dominant language and ideology, but female, is a significant way to make reform in language and its stereotyping effects on society. In this study, a feminist stylistic approach to Carter's stories will depict how Carter's use of language serves her feminist concerns. In her book, Sara Mills focuses on the importance "to challenge the gatekeepers of language, those institutions which have the power to give authority to certain meanings" (Mills, 1995, 126). Carter's stories should be accepted as some of the most noteworthy challenges both in English literature and others, via its world-wide translations. While ten stories constituting the book give female voice the opportunity to speak for itself, three of them, "The Bloody Chamber", "The Tiger's Bride" and "The Erl-King", narrated by female first-person narrators particularly convert the position of female as the object of traditional narrations to the subject of écriture féminine. Thus, by narrating her-story pro se, the female voice exercises power in these stories, in the words of Terry Eagleton. Accordingly, this study will examine these three stories with a feminist stylistic approach whose aim is "to document the ways in which gender difference is represented in texts in order to change the way that this happens" (Mills, 1995, 199). To reveal a systematic reading, the synoptic questions that are given in Feminist Stylistics by Sara Mills will be applied to Carter's selected stories. Mills gives "a list of possible questions which can be addressed to a text" and states that by this way "it will be possible for any text to be subjected to a thorough analysis of its representations of gender relations" (Mills, 1995, 199). The application of feminist stylistics to Carter's stories will include the answers to these questions and will be developed at three levels as Mills suggests in her 


\section{F.Ü. Sosyal Bilimler Dergisi 2016-26/2}

book: analysis at the level of the word, analysis at the level of the phrase/sentence, and analysis at the level of discourse all of which are in relation to gender issues.

To begin with an overall evaluation of Carter's style in terms of gender and writing/reading, some points such as the type of text, the target reader, the message, the addressee, and sentence structure should be focused on before analyzing the three levels.

\section{I-Context, Gender and Writing/Reading}

Carter's stories as re-writings of traditional fairy tales became very popular and won the Cheltenham Festival Literary Prize in 1979. As a female writer deconstructing fairy tales previously written by males, Carter has subverted the representational female and male characters. The target reader is both females and males like in the case of the earlier fairy tales, however with a new understanding of the reader's response to the text. As she decodes the gender roles that are strongly established in the reader's unconscious from the beginning of childhood by fairy tales, the book appears as a resistance against them. The reader therefore adopts a new and radical awareness of genderlect. It is a well-accepted notion that although some fairy tales seem to address both females and males, in many of them the addressee is females. In the traditional tales (such as "Little Red Riding Hood"), the texts contain ideological patriarchal messages, and there is almost a direct address to female characters warning them against males, sexuality, and liberty. In Carter's stories, the addressee is again predominantly female but the message is different. That's why stories written by a female for other females differ in style compared with fairy tales written by males for females.

Instead of an authoritative and masculine address, Carter's writing is non-prejudicial on behalf of females. Especially in the first-person narrations, the style appears female-oriented. To illustrate, "The Bloody Chamber" begins with a paragraph-size sentence summarizing the female narrator's state of mind with her own words:

I remember how, that night, I lay awake in the wagon-lit in a tender, delicious ecstasy of excitement, my burning cheek pressed against the impeccable linen of the pillow and the pounding of my heart mimicking that of the great pistons ceaselessly thrusting the train that bore me through the night, away from Paris, away from girlhood, away from the white, enclosed quietude of my mother's apartment, into the unguessable country of marriage. ${ }^{4}$

With this long sentence, the narrator is given the opportunity to tell her own story and express her emotions. The tone and length of the sentence indicate the unpredictable process of the marriage and put a negative suspicion on marriage. In general, Carter "uses the language of the story not to lull the reader into ignoring the dangers posed by Bluebeard but instead to heighten the reader's awareness of the threat posed by the sadomasochistic underpinnings of much of decadent culture, which created a dangerously passive and readily victimized feminine ideal" (Kaiser, 1994, 32).

In "The Tiger's Bride", as the possessive form suggests, the audience is prepared to read a story of confinement. The story begins as follows:

$$
\text { My father lost me to The Beast at cards. (51) }
$$

Effecting Subject Active Verb Effected Object

The short and sharp structure of the sentence expresses the feelings of the narrator; this time, not suspicion and melancholy but fury and attack. Brooke mentions that in this story, "[t]he daughter's

\footnotetext{
${ }^{4}$ Angela Carter. (1981). The Bloody Chamber. England: Penguin Books, p. 7. Subsequent references to The Bloody Chamber will be to this edition and will be included in the text.
} 
central weapon against her father is linguistic, manifesting the self-awareness, -containment, and respect that is reflected through her narrative (Brooke, 2004, 78).

Different from these two stories, "The Erl-King" begins with third-person narration with a descriptive sentence below:

The lucidity, the clarity of the light that afternoon was sufficient to itself; perfect transparency must be impenetrable, these vertical bars of a brass-coloured distillation of light coming down from sulphur-yellow interstices in a sky hunkered with grey clouds that bulge with more rain. (84)

Because this sentence is given in a gender-neutral way and does not adopt a specific feeling as it mixes "the clarity of light" with "grey clouds", the reader is given a frame of the outer world until the description changes into first-person narration:

The trees threaded a cat's cradle of half-stripped branches over me so that I felt I was in a house of nets and though the cold wind that always heralds your presence, had I but known it then, blew gentle around me, I thought that nobody was in the wood but me. (85)

Just after this compound sentence, the outer voice again interrupts the narration, saying:

The Erl-King will do you grievous harm. (85)

However, immediately after, narration again continues with subject pronoun "I" as if the outer voice is that of the reader who wants to warn the protagonist. As the text assumes, the reader has "certain elements of background knowledge" (Mills, 1995, 200), in other words, as the reader knows the story, s/he adopts a god-eye position in the reading process. This background knowledge draws on "stereotypical assumptions about [gender identities]" (Mills, 1995, 200). Still, Carter challenges the attitude of the reader afterwards by changing the events, and she finishes the story with a totally different conclusion. The text addresses a "universal audience" who should be prepared to face all possibilities in a fairy tale, not just happy endings. The last scene of "The ErlKing," in which the girl strangles the beast, is again narrated from the third-person point of view, creating an alienation effect. Rather than expressing emotion, the scene is given in a filmographic way as a natural incident, not less natural than male-murderers in fairy tales. All of the three stories mostly adopt an "intimate confessional autobiographical" (Mills, 1995, 200) approach in narration. Thus, the style of earlier fairy tales as masculine turns into a feminine discourse and stereotypes are deconstructed. Contrary to the female characters that are "ideally feminine-that is, passive and longsuffering - and defined by her sexual/maternal function" (Pitchford, 2002, 136), Carter makes the reader realize the possibility of anti-female-ideals. Observing Carter's demystifying gender roles at the level of the word, analyzing "individual lexical items" in the light of Mills' questions becomes significant.

\section{II- Analysis at the Level of the Word}

Whether language produces our perception of gender roles and sexism or it is a consequence of sexism in community is a contradictive issue. However, it is an undeniable notion -as linguistic determinism suggests- that "language produces our perception of the world" (Mills, 1995, 84). That is the reason why feminists require a language reform based firstly on the words. It is therefore significant to examine primarily how females and males are named in Carter's stories. In "The Bloody Chamber", we know that the first-person narrator is female, but her name is unmentioned. She is called "Madame" by workers at the castle and with some diminutive words such as "My little nun", "Baby" (17), "My little love", and "My child" (18) by her husband. The female narrator labels herself by some words such as "I, the orphan", "the châtelaine" and "I, the little music student" (13), "a little girl" (18), "child" (18), and "his bride" (13). It seems that she adopts the adjectives attributed to her by the outer world. On the other hand, the man she gets 


\section{F.Ü. Sosyal Bilimler Dergisi 2016-26/2}

married to holds an ancestral name of "The Marques" (36) which symbolizes mastery and power, and the heroine calls him, "my husband" and "my purchaser" (15). Nor in the other two stories do the female narrators mention their names. In "The Tiger's Bride" the male is called "The Beast" and in "The Erl-King" as "he or the Erl-King". Brooke states that in "The Tiger's Bride", the girl is "[u]nnamed because [of] disallowed self-identification or signification by her father and his society (Brooke, 2004, 77). Furthermore, Carter uses the common naming styles in these stories to create an atmosphere of a fairy tale, but later on, by transmitting the well-known ends into subversive alternatives, she challenges the male-dominated ideology.

When terms used to describe females and males are examined through their sexual connotations, Carter's feminist concern comes on the stage. Carter's stories are found mainly pornographic because of their overt use of sexuality, especially that of females. However, this language use is a result of her intention "to deal with the shifting structures of reality and sexuality" (Carter, 1998a, 25). Feminist critics generally criticize the "inequality of gender-specific terms" (Mills, 1995, 113) and they aim to reconstruct female sexuality. By examining different words used for the genitals of females and males, Mills emphasizes the androcentric naming of them (Mills, 1995, 103). In this sense, Carter's use of the word "loins" (66) in "The Tiger's Bride" and three more times in other stories is an example of refraining from androcentric terms for genitals. The title of her story collection, "The Bloody Chamber," is an overt reference to female genitals and female experiences of losing virginity and menstruation. In relation to describing sexual activity, Mills states that many terms such as "penetrate" present sex acts from the male perspective while female experience is given mostly by euphemisms (105). In this respect, Carter clearly gives connotations of female sexuality to naturalize the sexual experiences and femininities of women. For instance, in "The Bloody Chamber", the narrator resembles herself to a female figure in an etching described as "a lamb chop" (17), relates her sexual organ to a "scarlet, palpitating core" (15), and her first sexual experience as openly "bleeding" and "loss of virginity" (18). At this point, the general tendency to ignore sexuality that is in fact inherent in traditional fairy tales is deconstructed and made explicit by Carter. Thus, the taboos related to female experience such as loss of virginity (or menstruation in another story) is aimed to be demystified in these stories.

The themes that Carter tries to depict in her stories are greatly supported by metaphors. However, as Sara Mills suggests that a metaphor "works at the level of the phrase rather than at the level of words in isolation" (Mills, 1995, 136), it would be more suitable to shift the analysis to the level of phrase and sentence in these stories.

\section{III- Analysis at the Level of Phrase/Sentence}

The psychoanalyst Jacques Lacan founded the operation of the unconscious on metaphors and metonymies, which lead him to assert that "the unconscious is structured like a language" (Lacan, 1977, 149). The metaphors, by compensating meanings into one word, and the metonymies, by displacing one word with another, have great impact on both the unconscious of the individual and the collective unconscious of society. The narrations in folk traditions, here the fairy tales, play a significant role in strengthening and transforming the meanings inherited in metaphors. For this reason many feminists, including Angela Carter, subvert the connotations that some cliché metaphors hold, especially the ones in relation with gender issues.

Firstly, in many fairy tales, males and male sexuality are described with animal metaphors. While in "The Bloody Chamber" Marques is equated to a lion, in the other two stories the males are already a "tiger-beast" and "the Erl-king". The animal-like males who represent power and supremacy are demystified by Carter at the end of these stories by being murdered by female characters. Sara Mills explains how male sexuality is described with animal metaphors as follows:

Male sexuality is often described in terms of metaphors of animal behavior, as an animal's, and as little under control. The describing of sexuality in these terms 
means that extreme male behavior such as rape may be understood to be only 'natural'. (Mills, 1995, 137)

Animal metaphors are used on behalf of patriarchy in traditional fairy tales. Attacking the established metaphors that reinforce the naturalized knowledge, Carter discharges the meaning of animal metaphors, especially in "The Erl-King". In this story, she attributes domestic characteristics to the Erl-king ("he is an excellent housewife", "his kitchen shakes with bird song" and "his rustic home is spick" (87) ) but sexual appetite to the girl in the story: "Eat me, drink me; thirsty, cankered, goblin-ridden, I go back and back to him to have his fingers strip the tattered skin away and clothe me in his dress of water, this garment that drenches me, its slithering odour, its capacity for drowning" (89). The protagonist, who defines herself as "a perfect child" (89), transforms into a murderer and frees the captive birds (the "bird" metaphor generally representing weakness and tenderness is once again subverted) at the end of the story. Similarly, when the Beast in "The Tiger's Bride" wants to see the Beauty naked, "her pride" not "her shame" "thwarts her finger" (64) and she shows no fear in front of the Beast. Instead of holding the role of the "lamb", cliché imagery for female characters, she turns into a tiger at the end, when she exclaims: "The lamb must learn to run with the tigers" (64).

Some metaphors are mainly related to marriage or coupling in Carter's stories. The female characters are taken into closed spaces from the outer world by marriage or marriage-like intercourses. At this point, "journey" to the castle, to the woods or forest and into a house - in other words, into marriage or coupling space - carries an "uncanny" atmosphere in the stories. In "The Bloody Chamber", the train with the "clank of metal" takes the girl into the "silence of the night" and to the "dark platform" (11) that will be opened into married life. Additionally, the castle at which she arrives is a place of female confinement that carries the burden of wifehood and motherhood: "[T] hat magic place, the fairy castle whose walls were made of foam, that legendary habitation in which he had been born. To which, one day, I might bear an heir. Our destination, my destiny" (8). She refers to the castle with other metaphors and phrases such as:

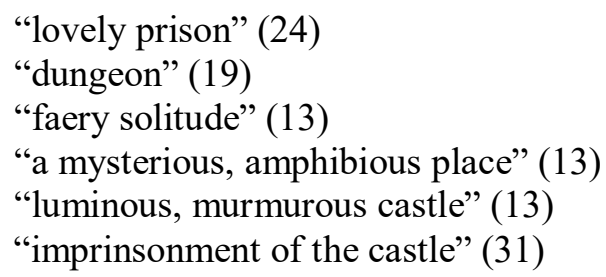

Thus, the journey to the castle, or to marriage, is foreshadowed as evil, and not as the beginning of happiness. Carter states that marriage "means the death of the virgin [...] hedged about with prohibitions that individualism might be" (Carter, 1998b, 401) and with these words above she clearly defines marriage as confinement.

In "The Tiger's Bride", the Beauty is lost to the Beast in Milan, a "dark, bitter city" (51):

This is a melancholy, introspective region; a sunless, featureless landscape, the sullen river sweating fog, the shorn, hunkering willows. And a cruel city; the sombre piazza, a place uniquely suited to public executions, under the heeding shadow of that malign barn of a church. (53)

The city stands as a metaphor of entrapment and foreshadows the fate of the Beauty. Similarly, in "The Erl-King", the girl's journey in the woods is an explicit representation of confinement:

"The woods enclose." (84)

"The wood swallows you up." (84)

In traditional fairy tales, the female characters are welcomed by a happy life, and at the end, by marriage, while Carter's stories begin with cold and exile-like marriages. In relation to marriage, 


\section{F.Ü. Sosyal Bilimler Dergisi 2016-26/2}

jewelry inspires metaphors referring to richness, but at the same time to the confinement of female characters. In "The Bloody Chamber" Marquis is "[t]he richest man in France" (12) and he gives "[a] choker of rubies, two inches wide, like an extraordinarily precious slit throat" (11) and "a gold band" (11) on her finger as a wedding gift that clearly represents captivation and even slavery of a female and dominance of an evil male.

The flower metaphor is another converted element in the stories. In traditional narrations, flowers are related to females with some connotations such as naivety, pureness and fragility. Carter decodes this metaphor in "The Bloody Chamber" by associating "white lilies" with the murderous Marques: "Yes. A lily. Possessed of that strange, ominous calm of a sentient vegetable, like one of those cobra-headed, funereal lilies whose white sheaths are curled out of a flesh as thick and tensely yielding to the touch as vellum" (9). With resembling the lilies to Marques's "white flesh", in other words to death, and the sheaths to his arms holding her, Carter conveys the idea that females do not have to be naïve and flower-like, and nor do flowers have to be harmless and related to females. By playing with established metaphors, she demystifies the earlier gendered assumptions in fairy tales. Sara Mills emphasizes that "[1]anguage is clearly not simply a place where meanings are imposed, but rather a site where certain meanings are negotiated over, or struggled over" (Mills, 1995, 103). In this sense, Carter's approach to metaphors appears as an attempt to this kind of struggle and negotiation on behalf of the female voice.

Apart from metaphors, an analysis at the level of phrase/sentence requires an approach to transitivity, according to Mills. By giving a schema representing material and mental processes in a narration, she proposes to analyze a text at the level of sentence. She claims that "if an author or speaker consistently chooses mental processes, a particular type of text will be produced" (Mills, $1995,144)$ and vice versa.
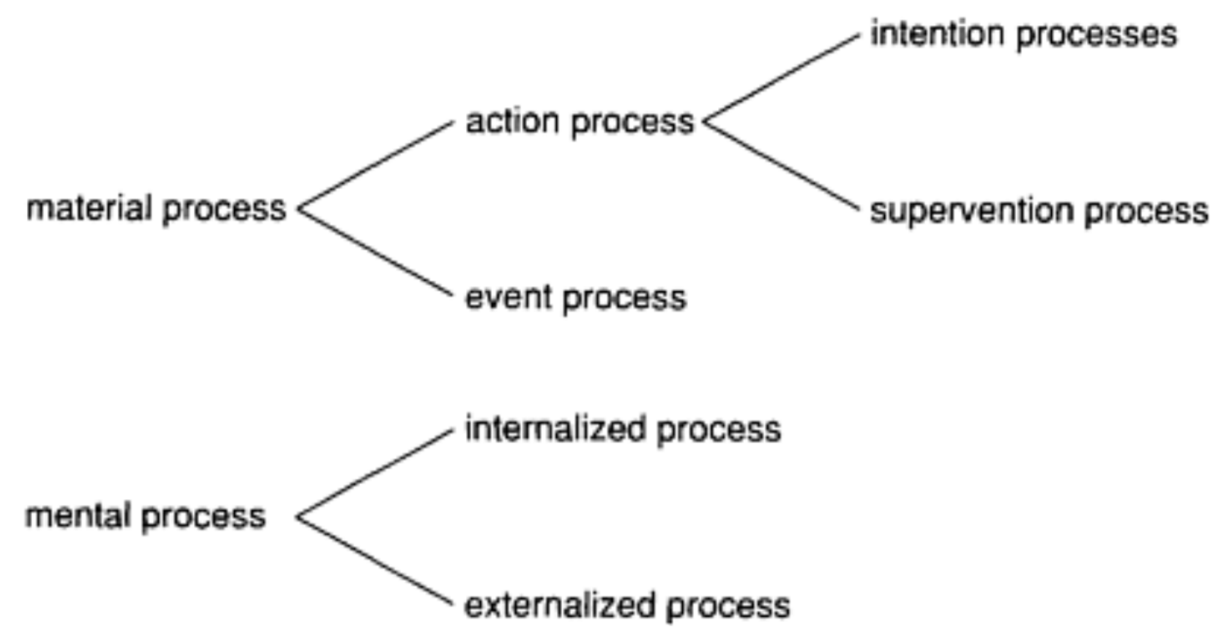

When traditional fairy tales and Carter's stories are compared according to this schema, it is apparent that material processes are dominant in the traditional tales, while mental processes, especially those of female characters, are mostly infused into the material ones in Carter's fiction. Besides, internal processes (such as to feel and to sense) are externalized. To Mills, "by analyzing patterns in transitivity choice it is possible to make more general statements about the way that characters view their position in the world and their relation to others" (Mills, 1995, 144). In traditional fairy tales, the protagonist whose actions and feelings are presented by an omniscient narrator -who is the voice of patriarchy- is mostly pictured as the passive object exposed to the actions of the outer world. An analysis at the syntactic level would clearly reveal this passiveness apparently, which makes the subject of another detailed study. When Carter's stories are examined at a syntactic level, it is easier to observe the active and passive, actor and sensor representatives, in relation to gender roles. As Mills states, "[t]he extent to which a character is the passive 'victim' of circumstance, or is actively in control of the environment, making decisions and taking action, is 
one of the concerns of feminist stylistics" (Mills, 1995, 144). When the active and passive roles of females are depicted in the three stories, one comes to the conclusion that those stories begin with passivity but end with activity on the side of females. In the beginning of "The Bloody Chamber", the marriage of the protagonist and her move into her new house are depicted in terms of her being a passive recipient of male action:

"my mother had been reluctant to see her girl whisked off by a man so recently bereaved" (10)

"he had invited me to join this gallery of beautiful women" (10)

In "The Tiger's Bride", many sentences allot the passive role to the female:

"My father lost me to The Beast at cards." (51)

"My father said he loved me yet he staked his daughter on a hand of cards." (54)

"Lost to The Beast!" (55)

"how I had been bought and sold, passed from hand to hand" (63)

"been alloted" (63)

"my father abandoned me to the wild beasts by his human carelessness" (63)

Similarly, the story of "The Erl-King" begins with the captivation of the girl by the Erl-King:

I saw the gaunt Erl-King, tall as a tree with birds in its branches, and he drew me towards him on his magic lasso of inhuman music. (89)

The male is the actor and female is the sensor, or, in other words, the affecting and affected become explicit in the scene of sexual intercourse in "The Erl-King":

His skin covers me entirely (89)

I should like to grow enormously small, so that you could swallow me (89)

His touch both consoles and devastates me (89)

Your green eye is a reducing chamber. If I look into it long enough, I will become as small as my own reflection, I will diminish to a point and vanish. I will be drawn down into that black whirlpool and be consumed by you. I shall become so small you can keep me in one of your osier cages and mock my loss of liberty. (90)

Carter's transitivity choice, namely "who does what to whom", at the beginnings of these stories makes the ideological message of traditional fairy tales, where the stereotypical females are pictured as passive victims and males as strong agents, explicit. However, Carter challenges the general tendency of traditional fairy tales in which "passivity is constructed as pleasurable" (Mills, 1995, 157). By converting passive recipients that are females into active agents after a while, she presents a deliberate transitivity choice related to her feminist concerns. In "The Bloody Chamber", the tone of the narration changes when the protagonist decides to discover the rooms in the castle. She becomes the agent to make decisions and to take action. When she wants to explore the "lovely prison", she feels exhilaration and her acts and sentences turn into commands:

Lights! More lights! [...] I ordered the servants to light up all their quarters [...] I adopted the crisp inflections of an officer's daughter. No, I would not dress for dinner. (24-25)

When she examines the rooms - except the one her husband has strictly forbidden her to enter - she is not satisfied with what she has found. She makes a fatal decision and proceeds to action: to open the forbidden chamber. This action strips her from her established role as a passive submitter:

I felt no fear, no intimation of dread. Now I walked as firmly as I had done in my mother's house. (27) 


\section{F.Ü. Sosyal Bilimler Dergisi 2016-26/2}

In spite of her brave attempt, Carter attributes the status of the strong female taking action not to the protagonist, but to her mother. When the protagonist loses all her power as soon as her husband discovers she has objected to his authority, her sentences reflect passivity once more:

I had been tricked into my own betrayal to that illimitable darkness whose source I had been compelled to seek in his absence [...]. (34)

However, her mother arrives in time to prevent her beheading by her husband and takes the position of the actor:

On her eighteenth birthday, my mother had disposed of a man-eating tiger that had ravaged the villages in the hills north of Hanoi. Now, without a moment's hesitation, she raised my father's gun, took aim and put a single, irreproachable bullet through my husband's head. (40)

Carter explicitly gives the position of power to the mother, as Marques is murdered by the heroine's mother with her husband's "antique service revolver" (8) like a "Medusa" (40) castrating phallic male desire and hegemony. "She appears at the conclusion as a complement to her daughter's masochistic passivity, just at the point when the bride herself has begun to act in her own behalf and emancipate herself from Bluebeard's pornographic scenario" (Kaiser, 1994, $33)$.

Similarly, "The Erl-King" ends with the female protagonist taking action to kill the ErlKing:

I shall take two huge handfuls of his rustling hair [...] and wind them into ropes

$[\ldots]$ and, softly, with hands as gentle as rain, I shall strangle him with them.

Then she will open all the cages and let the birds free [...]. (91)

Thus, the protagonists become actors at the end of the stories. In this respect, Carter's choice of transitivity functions to give a female-oriented perception of the tales. When analyses at the level of word and phrase-sentence are made, the data reveal a particular knowledge on the discourse within the stories. Therefore, an analysis at the level of discourse will mostly reflect the ideology in these stories and will be feminine discourse-oriented.

\section{IV- Analysis at the Level of Discourse}

It is inevitable that a feminist stylistic analysis should use discourse analysis to depict the explicit or implicit meanings and ideologies in a narration. The characters and gender roles constitute the most significant part of an analysis at the level of discourse. Sara Mills states that characters and gender roles that are attributed to them in texts are related to ideological concerns to a great extent, so they are just constructions:

Characters are made of words, they are not simulacra of humans -they are simply words which the reader has learned how to construct into a set of ideological messages drawing on her knowledge of the way that texts have been written and continue to be written, and the views which are circulating within society about how women and men are. (Mills, 1995, 160)

That's why the prominent element of a text, the character, holds within itself so many themes and ideas. To examine female and male characters in relation to certain topics will be illuminating to the messages Carter tries to deliver. The main topics in these stories are: marriage, sexuality, gender roles, and female liberty.

As mentioned earlier, in Carter's stories marriage does not automatically lead to a happy ending, as it happens in traditional fairy tales, but to a catastrophic beginning. Carter states that

the conventionalised "happy ending" of the wedding in fiction by and for women may signify not so much the woman's resignation of her status as autonomous 
individual, a status that might be at best problematic in a society with little available space for anybody's autonomy, but the woman's acquisition of a licence to legitimately explore her own sexuality in relation to a man, as well as acquiring part shares in her husband's public status and wealth, and inheriting all the folklore of sex and reproduction that is passed from generation to generation of married women. (Carter, 1998b, 400)

Reflecting her ideas above, in "The Bloody Chamber" marriage is an "unguessable country" (7) or "exile" (12) in which "a pang of loss" (7) is felt. When the Beauty in "The Tiger's Bride" arrives and is held captive, the country is described as "a sunless, featureless landscape" which brings to mind the connotation of the country of marriage. Similarly, in "The Erl-King", the girl is "trapped" in the green eyes of the Erl-King like the "trapped birds" whose cages he hangs on the kitchen wall, symbolizing a marital bond. Evoking Vladimir Propp's fairy tale functions, Sara Mills states: "[w]hen we consider these functions [...] [f]emales are often the recipients of actions or are the vehicle whereby a problem is solved, either through marriage or through being presented as a gift" (Mills, 1995, 169). Carter's attitude to marriage or a female character's being presented as a gift is contradictory in this sense because, by these actions the problem is not solved, rather the problem appears. The common problem in these stories is that the female characters experience a kind of confinement as a result of marriage or a similar association. Color imagery works to strengthen the theme of marriage as constraining, and the color red representing blood, wound, and death indicates the death of female desire, freedom, and self-actualization in male-dominant marriages. In "The Bloody Chamber", marriage-related issues are associated with the red color:

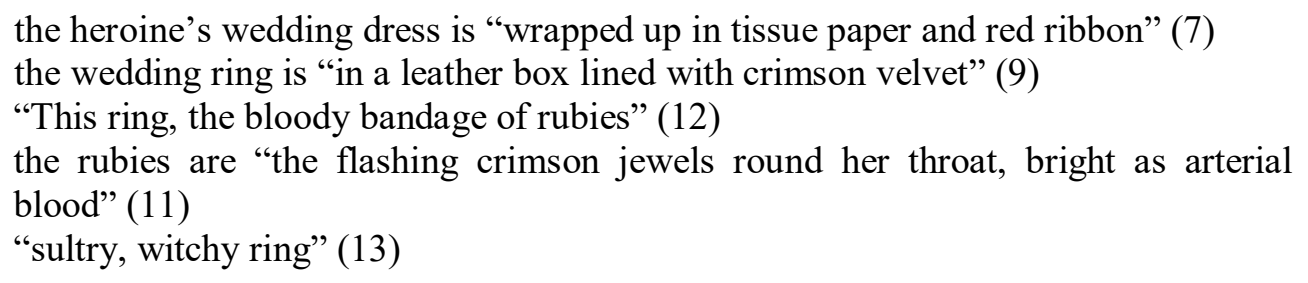

The color red is strictly related to female experience and female identity in the stories. Before all else, the title of "The Bloody Chamber" is a symbol of a vagina representing a female experience that passes through confinement to freedom.

The feeling of confinement is related to sexual roles and female sexuality in general, which is another main topic in the stories. Carter "treats sexuality as a political reality [and] reexamines levels of constraints and meaning, finding that sexual restriction in part lies in social and cultural repressions as well as economic inequities" (Brooke, 2004, 76). Traditional fairy tales implicitly picture female characters as exposed to male sexuality and male sexual appetite. Carter handles the issue of sexuality in a reformative way on behalf of females. While female sexuality, the loss of virginity, and female desire are not mentioned or just implied indirectly as an unwelcomed matterof-fact in the traditional tales, Carter makes these experiences explicit and redefines them. She moves the perception of "loss or end of innocence" to the realm of "female experience" of her own body. "Once Carter's women explore assertive sexuality, they face Bluebeard's intention of annihilating them (Pyrhönen, 2007, 88-9)"; however, Bluebeard is also faced with the danger of being annihilated by women. In "The Bloody Chamber", when the protagonist realizes her sexual desire, she tells: "for the first time in my innocent and confined life, I sensed in myself a potentiality for corruption [italics added] that took my breath away" (11). Against many narrations that situate females into the status of sexual object, Carter questions male voyeurism that is naturalized by these narrations. It is a general tendency that female characters are portrayed as objects to be watched and subjected to a position of voyeurism. On the contrary, Carter places male characters into the status of sexual object, partly through female voyeurism. In "The Bloody Chamber", Marques is observed and described as a man with "so strangely red lips" (13) and a "white body" by his wife. On the twelve mirrors covering their bedroom, the female protagonist 


\section{F.Ü. Sosyal Bilimler Dergisi 2016-26/2}

watches him more than he watches her. Notable female voyeurism appears in "The Tiger's Bride" when the Beauty wants to see the Beast naked, as a response to his voyeurism. She monitors and describes his beastly body in detail, as follows: "A great, feline, tawny shape whose pelt was barred with a savage geometry of bars the colour of burned wood. His domed, heavy head, so terrible he must hide it. How subtle the muscles, how profound the tread. The annihilating vehemence of his eyes, like twin suns" (64). When the valet wants to cover up his master, the Beauty stops him and continues to look attentively. So, in this way, the Beast becomes subjected to the position of an object. In "The Bloody Chamber", male voyeurism is demystified by Jean-Yves, the blind piano tuner who becomes the protagonist's love in a short span of time. At the end of the story, she mentions "I know he sees me clearly with his hearth" (41) - this suggests no female flesh and no voyeurism is at stake now. Instead of creating hostility towards males, Carter suggests an acceptable kind of male identity that does not have voyeuristic appetite. In "The Erl-King", the female character is enchanted by the Erl-King's attractiveness at the beginning: "His skin is the tint and texture of sour cream, he has stiff, russet nipples ripe as berries. Like a tree that bears bloom and fruit on the same bough together, how pleasing, how lovely" (88). Although she is one of the many girls who have been captivated by the Erl-King's charm, Carter gives her the opportunity to get through this captivation. Accordingly, when female sexuality is normalized, the freedom is left into the hands of the female in the story. "Carter, thus, establishes a difference between "real relations that change you' and sexuality reduced to mechanical bodies and acts" (Cook, 2014, 951).

Carter's demystifying of the marriage and sexuality issues serves her aim to create a new point of view on gender roles. While traditional fairy tales mainly uses "he-man language", Carter pictures the world of female characters by using a female narrator-focalizer who "is the sole source of vision, information and judgement on the characters and events" (Mills, 1995, 87, 180). In this way, the established gender roles are decoded and new roles are presented. Initially, the mother figure in "The Bloody Chamber" reverses both gender roles and family bonds in the traditional tales. This story, as a retelling of "Blue Beard", puts the mother figure into the center of the story, contrary to the traditional "Blue Beard" in which the brothers and the father save the girl from being murdered. The mother figure in "The Bloody Chamber" is extraordinarily brave; instead of a father or brother figure, she is the savior of her daughter. Presented as an alternative of the passive and excluded mothers in many traditional fairy tales, she is described as follows:

There was a [wedding] dress for her, too; black silk, with the dull, prismatic sheen of oil on water, finer than anything she'd worn since that adventurous girlhood in Indo-China, daughter of a rich tea planter. My eagle-featured, indomitable mother $[\ldots]$ had outfaced a junkful of Chinese pirates, nursed a village through a visitation of the plague, shot a man-eating tiger with her own hand and all before she was as old as I. (7)

While in "The Bloody Chamber" there is no father figure, in "The Tiger's Bride" the father is extremely brute and selfish, so much so that he loses his daughter through gambling. In the story, no sympathy is shown for his fault. His attempt to show his remorse is narrated by the Beauty as follows: " "Like the base Indian," ' he said; he loved rhetoric. " One whose hand,/Like the base Indian, threw a pearl away/Richer than all his tribe ..." I have lost my pearl, my pearl beyond price' (55). In response to his insincere confession, the Beast's reply appears as if the reader's reaction: "If you are so careless of your treasures, you should expect them to be taken from you" (55). When these two stories are compared, Carter explicitly puts the affection of the mother against the selfinterest of the father, who sees his daughter as his commodity. The gender roles are also deconstructed in terms of the private corporations of females and males. The common notion of female passivity in the traditional tales is abolished in Carter's stories. When the girl in "The Bloody Chamber" realizes that Marques has chosen her because of her "innocence" and "the silent music of her unknowingness", her "shock of surprise" (19) reveals that it is not a natural and acceptable idea. In "The Tiger's Bride", the Beauty is in great contrast to a traditional female role, as she represents action more than emotion. Instead of staying in her human appearance, she 
transforms into a magnificent tiger at the end, to be equivalent to the Beast. According to Brooke, that the Beauty's skin is being ripped off "skin after successive skin, all the skins of a life in the world, and left behind a nascent patina of shiny hairs [...] her beautiful fur" (64) represents "the stripping of 'socialized virtues', heralded by The Sadeian Woman as a way of returning 'to the primal and vicious states of nature" "(Brooke, 2004, 83). While the heroine of "The Erl-King" begins as a passive victim of male power, at the end she murders the Erl-King in cold blood that totally demystifies the weak and passive role of females in traditional fairy tales.

These stories narrated from the view of three female characters explicitly reveal the idea of female liberation. In "The Bloody Chamber", the girl, her mother and her lover begin to live a quiet life in the castle that is turned into a school for the blind and a partnership with the blind pianotuner, not a marriage, signifies the avoidance from marital bonds. In "The Tiger's Bride", the Beauty is stripped of "all the skins of a life in the world" and reborn with "a nascent patina of shining hairs" (67). Lastly in "The Erl-King", after the girl strangles the Erl-King, she opens all the cages and lets the birds free that "will change back into young girls, $[\ldots]$ each with the crimson imprint of his love-bite on their throats" (91). Furthermore, she carves off his great mane and strings "the old fiddle with five single strings of ash-brown hair" that will play "discordant music without a hand touching it" (91). In conclusion, Carter silences the male voice in the three stories. In "The Tiger's Bride", the Beast cannot say a word but speak via his valet; at the ends of "The ErlKing" and "The Bloody Chamber" the murder of evil males ultimately brings female liberation.

\section{Conclusion}

Feminist stylistics, which has its roots both in feminism and stylistics, "has suggested ways in which those concerned with the representation of gender relations might draw on linguistic and language analysis to develop a set of tools which could expose the workings of gender at a range of different levels in texts" (Mills, 1995, 198). This study has aimed to examine Angela Carter's feminist concerns in her three stories that deconstruct the traditional patriarchal fairy tales. When the analysis is held out at the level of word, phrase, and discourse, it is clearly observed that Carter subverts the established ideologies and stereotyping on gender roles, with a feminist interest. Accordingly, by perceiving the power of language as producing and intensifying sexism, she not only deconstructs the sexist meanings in the earlier fairy tales but presents alternative stories to undermine the oppression of females via language. She aims to "call attention to the literary fairy tale as a product not of a collective unconscious but of specific cultural, political, and economic positions" (Kaiser, 1994, 35). By contrasting traditional gender roles in fairy tales, in which female characters are pictured as weak, passive, and extraordinarily naïve, Carter creates a new world of strong, brave, and even cruel and evil female protagonists. In the "Polemical Preface" to her book The Sadeian Woman and The Ideology of Pornography, Carter states the mythic versions of women as "consolatory nonsenses" and she warns women against interiorized submission:

If women allow themselves to be consoled for their culturally determined lack of access to the modes of intellectual debate by the invocation of hypothetical great goddesses, they are simply flattering themselves into submission (a technique often used on them by men). (Carter, 1978, 5)

It is apparent that Carter opens the way to a new point of view that operates with free will of female identity in her stories, using new content and style that is foreign to traditional fairy tales, standing against that internalized submission. This aim is parallel with the objective of feminist stylistics that has been the main focus of this study. 


\section{References}

Brooke, Patricia. (2004). "Lyons and Tigers and Wolves-Oh My! Revisionary Fairy Tales in the Work of Angela Carter". Critical Survey (Oxford, England), Vol. 16, No. 1, pp. 67-88.

Carter, Angela. (1998a). "Notes from the Frontline". Critical Essays on Angela Carter (Ed. Lindsey Tucker). New York: Hall. 24-32.

Penguin Books.

(1998b). Shaking a Leg: Collected Writings (Ed. Jenny Uglow). New York\&London:

(1981). The Bloody Chamber. England: Penguin Books.

Books.

(1978). The Sadeian Woman and The Ideology of Pornography. New York: Pantheon

Cook, Hera. (2014). "Angela Carter's 'The Sadeian Woman' and Female Desire in England 19601975”. Women's History Review, 23:6, pp. 938-956.

Eagleton, Terry. (2003). After Theory. New York: Basic Books.

Haffenden, John. (1985). “Angela Carter”. Novelists in Interview. New York: Methuen Press.

Joannou, Maroula. (2007). "Rereading Angela Carter”. Women: A Cultural Review, 18:1, pp. 110-2.

Kaiser, Mary. (1994). "Fairy Tale as Sexual Allegory: Intertextuality in Angela Carter's The Bloody Chamber". The Review of Contemporary Fiction, Vol. 14, No. 3, pp.30-6.

Lacan, Jacques. (1977). The Seminar of Jacques Lacan: Book XI The Four Fundamental Concepts of Psychoanalysis (Ed. Jacques-Alain Miller), (Trans. Alan Sheridan). New York-London: W. W. Norton\&Company.

Mills, Sara. (1995). Feminist Stylistics. London: Routledge.

Pitchford, Nicola. (2002). Tactical Readings: Feminist Postmodernism in the Novels of Kathy Acker and Angela Carter. Lewisburg: Bucknell University Press.

Pyrhönen, Heta. (2007). "Imagining the Impossible: The Erotic Poetics of Angela Carter's 'Bluebeard' Stories". Textual Practice, 21:1, pp. 93-111.

Ufot, Bassey Garvey. (2012). "Feminist Stylistics: A Lexico-grammatical Study of the Female Sentence in Austen's Pride and Prejudice and Hume-Sotomi's The General's Wife". Theory and Practice in Language Studies, Vol. 2, No. 12, pp. 2460-70. 